Kapata Arkeologi, 12(2), 163-174

ISSN (cetak): 1858-4101

ISSN (elektronik): 2503-0876

http://kapata-arkeologi.kemdikbud.go.id

\title{
SITUS PULAU UJIR DI KEPULAUAN ARU: KAMPUNG KUNO, ISLAMISASI DAN PERDAGANGAN
}

\section{Ujir Island Sites in Aru Islands: Ancient Village, Islamisation and Trade}

\author{
Wuri Handoko \\ Balai Arkeologi Maluku - Indonesia \\ JL. Namalatu-Latuhalat Ambon 97118 \\ wuri_balarambon@yahoo.com
}
Naskah diterima: 14/09/2016; direvisi: 18/11 - 08/12/2016; disetujui: 15/12/2016
Publikasi ejurnal: 30/12/2016

\begin{abstract}
Ujir ancient village on the island, is the site of settlement that shows the development of the Islamic period and colonial settlements in the territory of Aru Islands. Various archaeological data has been discovered, indicates the site serves as a growing settlements with the activities of the Muslim settlers and until recently has shown progress as one of the Muslim villages were quite advanced in the Aru Islands. This study is to explore the traces of Islamization and commercial developments in the Aru Islands, with the main focus in the Ujir Island to analyze the are role in the development of Islamization and commerce in the Aru Islands in the past. Study focused on the archaeological data collected from survey and excavation. The results showed that the old village site Ujir Island, called Site Uifana, is the site of settlements in the past is likely to be one of the centers spread of Islam in the Aru Islands which was later destroyed and abandoned during the influence of the entry of European colonization and later the Japanese. Ujir Island may also be a bridge in trade flows involving the surrounding area in the path of the spice trade and exotic commodities of Aru Islands.
\end{abstract}

Keywords: Islamization, trade, settlement, Uifana, Aru Islands

\begin{abstract}
Abstrak
Kampung kuno di Pulau Ujir, merupakan situs permukiman yang menunjukkan perkembangan permukiman masa Islam dan kolonial di wilayah Kepulauan Aru. Penelitian ini menemukan, berbagai data arkeologi yang menunjukkan bahwa Pulau Ujir merupakan situs pemukiman yang maju dan berperan dalam jaringan Islamisasi dan perdagangan di kawasan Kepulauan Aru. Hasil penelitian memperliatkan bahwa situs kampung tua Pulau Ujir, yang disebut Situs Uifana, adalah situs permukiman yang pada masa lampau menjadi salah satu pusat penyebaran Islam yang kemudian hancur dan ditinggalkan pada masa pengaruh kolonialisasi Eropa dan Jepang. Pulau Ujir juga menjadi jaringan perdagangan yang melibatkan kawasan sekitarnya dalam jalur perdagangan rempah dan komoditi eksotik, seperti burung cendrwaasih dan mutiara di Kepulauan Aru.
\end{abstract}

Kata kunci: Islamisasi, perdagangan, permukiman, situs Uifana, Kepulauan Aru

\section{PENDAHULUAN}

Pengetahuan awal soal Kepulauan Aru, pertama kali diperkenalkan oleh seorang Alfred Russell Wallace seorang naturalis Inggris yang tiba di Dobo tepatnya di Pulau Wamar pada pertengahan abad ke-19 yang bertugas melakukan suatu eksplorasi wilayah-wilayah Timur (1854-1862) (Wallace, 2009). Ia menyebutkan pulau-pulau Aru sebagai The Promised Land (tanah terjanji) hal mendasar yang didapatkan dari teori ilmuwan ini adalah keagungan atas keanekaragaman hayati Kepulauan Aru dan jenis kerang laut yang belum pernah dilihatnya di belahan dunia lain. Hasil penelitian Wallace di Aru kemudian disatukan sebagai sebuah karya ilmiah bersama kajiannya yang juga mencakup wilayah lain di Asia Tenggara yang dikunjunginya. Dalam buku berjudul The Malay Archipelago ini, Wallace mengemukakan teorinya, dengan mengacu pada distribusi hewan dan burung, ilmuwan dunia ini mengumpulkan lebih dari 9000 spesimen objek 
alam dari 1600 spesies (Wallace, 2009; Wakim, 2014: 24).

Penelitian arkeologi di Kepulauan Aru dimulai pada tahun 1995 (O'Connors, et.al, 2006), setelah beberapa sebelumnya eksplorasi arkeologi di Wilayah Kei Kecil (Ballard, 1988, 1992; Spriggs dan Miller, 1988). Laporan awal dari proyek penelitian itu, sebelumnya lebih awal telah dipublikasikan antara lain O'Connor et al. (2002a), Spriggs et al. (1998), dan Veth et al. (1998a, 1998b, 2000). Bukti arkeologi di Kepulauan Aru antara lain: pertama: sifat dan tingkat kolonisasi maritim dan pemukiman awal Homo Sapiens pada masa Pleistosen, dan dampak berikutnya dari pemukiman pada lanskap pulau yang sebelumnya kosong; kedua: tingkat konektivitas antarpulau, kontak dan pertukaran di masa awal Pleistosen dan Holosen, seperti yang ditunjukkan oleh bukti yang berkaitan dengan translokasi spesies hewan, tumbuhan dan komoditi eksotis; ketiga: asalusul dan kronologi pengenalan pertanian dan domestikasi hewan dan dorongan untuk pengembangan adopsi pertanian oleh masyarakat pra-pertanian; keempat: interaksi antara kelompok-kelompok pribumi dan masuknya pemukim Austronesia; dan kelima: peran Aru sebagai pemasok bulu burung surga (burung cendrawasih), produk hutan dan kelautan ke pasar dunia selama 2000 tahun.

Dalam sejarah penelitian arkeologi di wilayah Kepulauan Aru, potensi data arkeologi Islam, selama ini kurang mendapat perhatian. Sejauh penelitian yang sudah dilakukan lebih banyak mengacu pada data arkeologi prasejarah dan etnografi. Sementara itu penelitian arkeologi Islam hampir tidak pernah menjangkau wilayah ini. Rekam jejak penelitian arkeologi, justru dimulai ketika para peneliti Australia, melalukan penelitian arkeologi di wilayah Kepualuan Aru untuk menelusuri jejak okupasi manusia sepanjang masa plestocen dan holocen. Sementara itu penelitian arkeologi Islam, selama ini belum tergarap. Beberapa hal penyebab tidak adanya penelitian arkeologi Islam di Kepulauan Aru, mengingat hampir tidak ada sumber pustaka yang menyebut wilayah kekuasaan Ternate dan Tidore mencapai wilayah Kepulauan Aru.

Berbagai sumber sejarah, Ternate dan Tidore adalah dua kerajaan di wilayah Maluku Utara yang dapat dipresentasikan sebagai wilayah pusat kekuasaan Islam di wilayah
Maluku Utara. Ternate, memperluas kekuasaan ke wilayah selatan Maluku, meliputi Pulau Ambon, Haruku, Saparua, Buru, Seram Bagian Barat dan Tengah. Sementara itu Tidore meluaskan kekuasaannya ke wilayah pesisir utara Pulau Seram dan wilayah kepulauan di sisi paling timur Pulau Seram, yakni Gorom dan Seram laut hingga ke wilayah Kepulauan Raja Ampat Irian Jaya. (Leirissa, 2001: 8). Dapat dianggap kedua wilayah kesultanan itu saling bersasing kekuasaannya hingga keluar wilayah geografisnya ke wilayah pulau-pulau diseberang lautan. Selain kekuasaan yang politis, kerajaankerajaan besar tersebut juga menyebarkan dan mengembangkan paham-paham kultural. Salah satunya adalah penyebaran dan pengembangan agama Islam di wilayah-wilayah kekuasaan tersebut. Pengislaman 'wilayah seberang' kesultanan Ternate, tidak lepas dari peranan pusat kekuasaaan itu sendiri (Putuhena, 2001: $62)$.

Hubungan antara Islamisasasi dan perdagangan, merupakan salah satu isu yang terus diperbincangkan. Perdagangan di satu sisi dan Islamisasi di sisi lain tampaknya seperti dua mata keping uang yang saling bersinggungan. Meskipun diantara para ahli ada pula perbedaan pendapat soal itu. Ricklefs (2008) menuliskan bahwa antara Islam dan perdagangan tampaknya ada semacam kaitan, meskipun banyak pertanyaan-pertanyaan yang belum terjawab, mengingat perdagangan oleh orang-orang muslim telah ada beberapa abad sebelum masa pengislaman Nusantara yang baru terjadi pada abad XIII, XIV dan XV (Ricklefs, 2008: 37-38). Penjelasan tersebut memberikan gambaran bahwa proses perdagangan di wilayah Nusantara berlangsung jauh sebelum Islam berkembang, sehingga jika Islamisasi berlangung sejak dimulainya era perdagangan oleh bangsa-bangsa penyebar Islam, semestinya Islam tumbuh dan berkembang sejak masa itu. Namun, satu hal yang tidak dapat dipungkiri bahwa proses perdagangan yang berlangsung telah memperkuat eksistensi Islam di Nusantara. Tjandrasamita memperkuat dengan penjelasan bahwa munculnya jalur perdagangan sejak masa awal telah memicu terjalinnya jaringan perdagangan dan pertumbuhan serta perkembangan kota-kota pusat kesultanan, dengan kota-kota bandarnya sejak abad 13-18 M (Tjandrasasmitha, 2009: 39). 


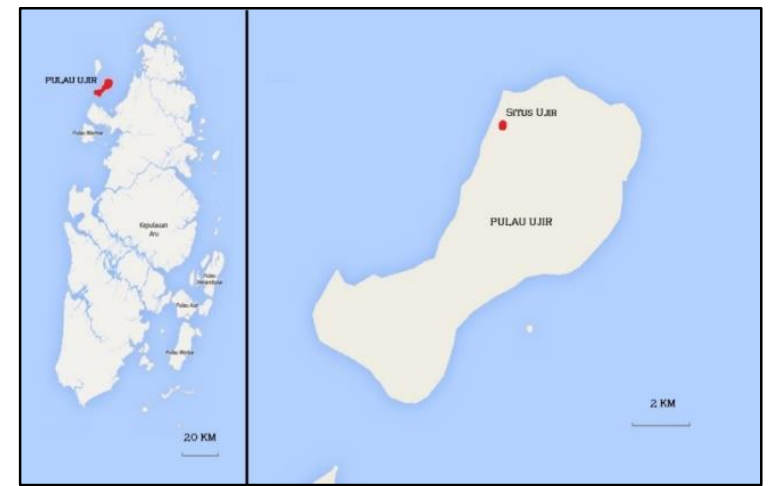

Gambar 1. Peta Situs Pulau Ujir

(Sumber: Tim Penelitian, 2014)

Berdasarkan landasan teoritis demikian, maka posisi wilayah Kepualuan Aru dapat diassumsikan sebagai lintasan pelayaran dan perdagangan, sekaligus jalur gerak Islamisasi dari para pedagang muslim dari berbagai wilayah. Tinjauan masalah yang penting dalam studi ini meliputi, pertama bagaimana proses Islamisasi jika ditinjau berdasarkan temuan situs pemukiman di wilayah Pulau Ujir, Kepulauan Aru? Bagaimana jejak perdagangan masa Islam berdasarkan potensi arkeologi yang terdapat di Pulau Ujir, Kepulauan Aru? Pertanyaanpertanyaan penelitian menyangkut sejak kapan pemukiman di Pulau Ujir muncul, serta kapan masyarakat mengkonversi Islam sebagai agama, serta bagaimana perkembangan pada awal-awal Islam masuk serta pengaruhnya di wilayah lainnya di Kepulauan Aru, merupakan isu-isu penelitian yang cukup aktual dan belum terjawab. Untuk itu penelitian di wilayah ini merupakan penelitian arkeologi sejarah untuk merekonstruksi sejarah perkembangan Islam sekaligus menggambarkan jalur pelayaran dan jaringan niaga yang melibatkan wilayah tersebut. Mengingat penjelasan itu, maka studi ini menitikberatkan temuan arkeologi berupa situs pemukiman yang diduga kuat sebagai situs pemukiman Islam, untuk menjangkau penjelasan tentang kronologi dan proses Islamisasi di wilayah Kepulauan Aru.

\section{METODE}

Penelitian ini adalah sebuah penelitian arkeologi sejarah yang menitik beratkan penemuan dan penggalian data untuk menelusuri jejak-jejak sejarah peradaban. Oleh karena itu data utama yang digunakan dalam penelitian ini data arkeologi yang ditemukan berdasarkan survei permukaan dan ekskvasi di lokasi penelitian. Lokasi penelitian adalah di Pulau Ujir, yakni di situs permukiman kuno yang disebut situs Uifana. Penelitian di lokasi itu selain berdasarkan informasi penduduk, juga berdasarkan referensi pustaka. Selain itu melakukan wawancara etnografis pada penduduk yang bermukim di sekitar situs di Pulau Ujir juga metode yang mutlak dilakukan, mengingat penduduk Pulau Ujir sekarang adalah keturunan dari para penduduk yang bermukim situs pemukiman kuno Uifana pada masa lampau.

\section{HASIL DAN PEMBAHASAN \\ Situs Kampung Lama Uifana dalam Konteks Islamisasi}

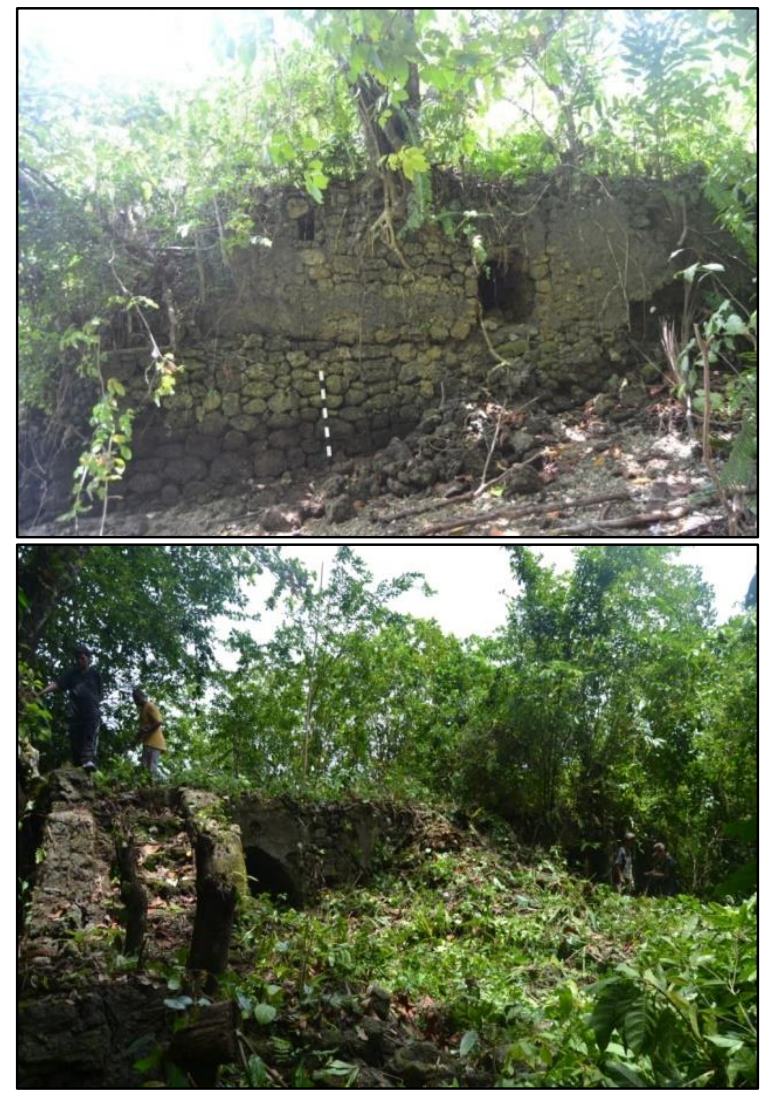

Gambar 2. Struktur Bangunan yang disebut penduduk setempat sebagai bekas bangunan masjid (Sumber: Tim Penelitian, 2014)

Dalam historiografi lokal, di wilayah Kepulauan Aru, meskipun tidak berkembang kerajaan-kerajaan Islam, namun bukan berarti tidak ada pengaruh Islam di wilayah itu. Penyebaran Islam mungkin tidak luas, hanya mencakup beberapa pulau yang terjangkau. Kondisi ini mungkin disebabkan berbagai faktor, antara lain: pertama, kemungkinan penyebaran 
Islam, hanya di wilayah-wilayah yang paling mudah dijangkau. Hal ini disebabkan kemungkinan keterbatasan teknologi pelayaran pada saat itu. Kedua, kedatangan gelombang bangsa asing Eropa yang tidak terpaut jauh dengan kedatangan Islam, menimbulkan persaingan dan menyebabkan terbatasnya ruang gerak Islamisasi. lokal Pulau Ujir Kepulauan Aru. Bukti lain ditunjukkan oleh adanya temuan keramik dari abad 16-17. Perdagangan lebih berkembang setelah masuknya Kolonial pada abad 18-19 M. Selain itu, konflik dengan pendatang Eropa mungkin juga tidak terhindarkan dan menjadi bagian dari dinamika sejarah budaya masyarakat Ujir pada masa lampau sebelum kemudian

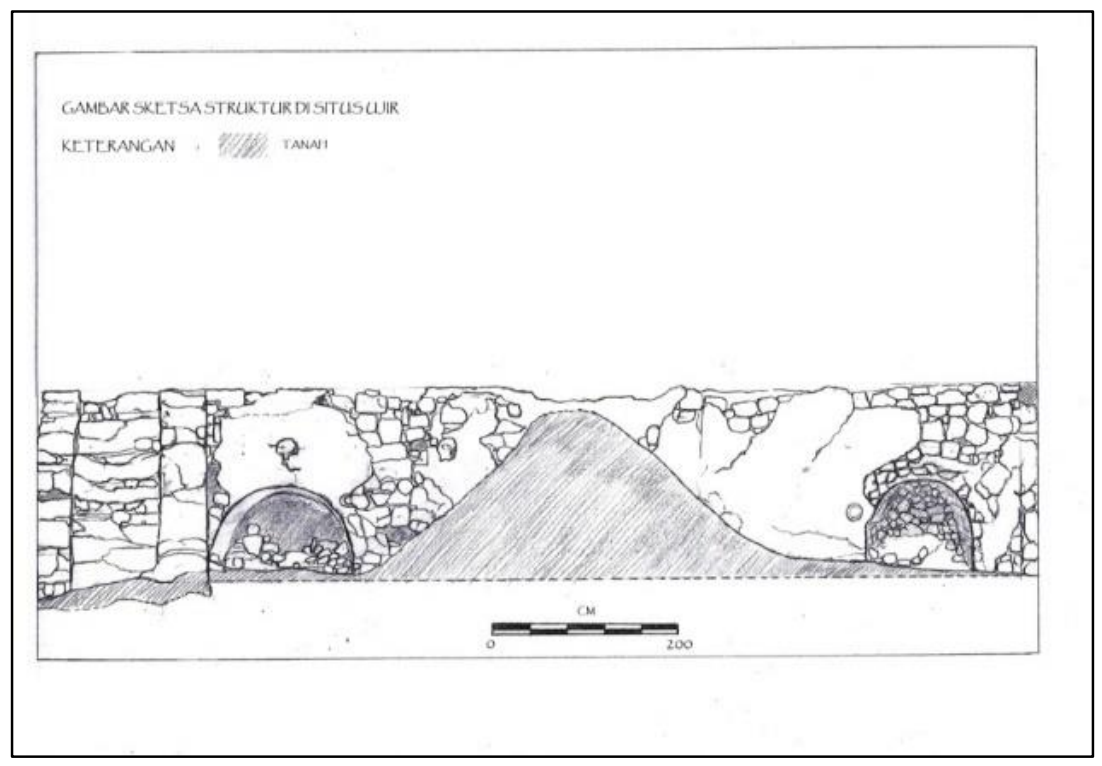

Gambar 3. Sketsa struktur bangunan bekas masjid kuno, dilihat dari arah depan atau sebelah selatan

(Sumber: Tim Penelitian, 2014)

Berdasarkan temuan-temuan yang ada, diduga situs kampung kuno Uifana di Pulau Ujir, telah ada sejak awal perkembangan Islamisasi di Kepulauan Aru. Menurut tradisi tutur yang berkembang, masjid kuno Uifana pada masa lampau beratap tumpang tiga dengan tiang alif yang menjadi ciri khas masjid-masjid yang berkembang pada abad ke-16 hingga $17 \mathrm{M}$. Tetapi, struktur bangunan menunjukkan ciri dominan bangunan Eropa. Hal ini mungkin menjelaskan bahwa setelah penjajah Eropa meninggalkan Pulau Ujir, benteng peninggalan mereka dialihfungsikan sebagai masjid. Veth (2005) mengatakan bahwa struktur bangunan berciri Eropa tersebut adalah Benteng Portugis atau Benteng Belanda. Namun bukti arkeologi kolonial ini, kurang didukung bukti catatan sejarah, tentang pengaruh Portugis dan Belanda di Kepulauan Aru. (Villiers, 1981: 74; Veth, et.al, 2005 ).

Adanya pemukiman dengan ciri atau karakteristik Islam yang menonjol, menunjukkan intensifnya para pedagang dan penyebar Islam, berhubungan dengan penduduk berpindah dan menetap di pemukiman sekarang. Temuan data arkeologi di Pulau Ujir memberi informasi baru, bahwa terdapat pusat penyebaran Islam di Kepulauan Aru, yakni terletak di Pulau Ujir, yang mungkin menunjukkan pemukiman Islam tertua. Temuan benteng-benteng tradisional (lutur), yang terbuat dari susunan batu, di permukiman kuno Ujir, tampaknya telah ada sebelum bangunan besar di pinggir sungai yang disebut oleh masyarakat sebagai bangunan masjid yang berciri bangunan Eropa. Temuan susunan batu ini, menandai bahwa pemukiman tradisional telah berkembang pada masa pra kolonial. Adanya susunan batu (lutur) merupakan bukti adanya pola pemukiman yang sudah tertata. Sumber tutur setempat menerangkan, ruang-ruang permukiman pada masa lalu, sudah terpola berkelompok-kelompok berdasarkan marga-marga. Bukti arkeologi di lapangan menunjukkan susunan batu yang teratur dan bersekat-sekat memberi gambaran adanya pembagian ruang yang teratur.

Bukti pemukiman Islam yang berkembang sebelum kedatangan kolonial, 
merupakan pertanyaan yang penting dan cukup aktual dalam memberikan gambar sejarah Islam di Kepulauan Aru. Rentang waktu pengaruh Islam dan kolonial yang tidak terpaut jauh, menyebabkan sulitnya memastikan waktu kedatangan Islam. Hal ini juga berkaitan dengan perkembangan niaga baik pada masa Islam maupun kolonial.

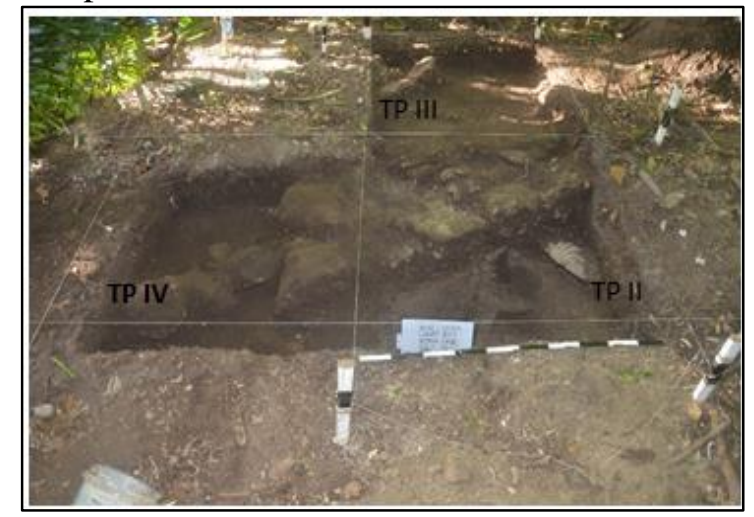

Gambar 4. Temuan struktur yang tersingkap dari penggalian di kotak kemungkinan menunjukkan struktur yang lebih tua, sebelum adanya bangunan yang tampak di permukaan

(Sumber: Tim Penelitian, 2015)

Bukti-bukti artefaktual tentang kronologi perkembangan niaga dan pengaruh religi di dalamnya, sejauh ini baru ditunjukkan oleh kuantitas dan kualitas keramik. Di antara tinggalan arkeologi yang dihimpun, hasil analisis pertanggalan keramik dapat digunakan untuk menentukan umur situs. Selain keramik, juga menggunakan analogi sumber-sumber tutur yang berkembang pada masyarakat setempat.

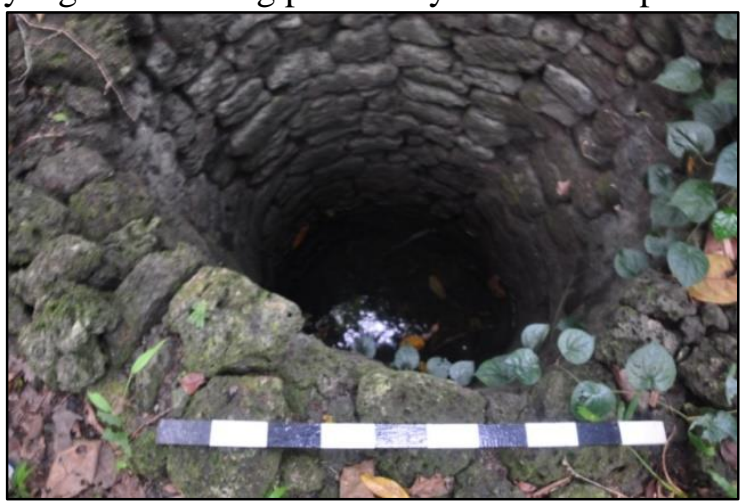

Gambar 5. Parigi yang terletak di tengah-tengah situs permukiman Uifana

(Sumber: Tim Penelitian, 2014)

Situs Kampung Uifana adalah sebuah situs permukiman masyarakat Ujir pada masa pengaruh Islam dan Kolonial. Di situs tersebut berbagai data arkeologi, potensial untuk mengungkap sejarah budaya dan kehidupan masyarakat penghuninya pada masa lampau. Situs ini bisa dikatakan sebagai situs permukiman terlengkap yang pernah ditemukan di wilayah Kepulauan Aru, terutama hubungannya dengan masa pengaruh dan perkembangan Islam dan periode sesudahnya. Menurut sumber tutur (Jafar Hatala, pers.com, 2014) kampung lama Ujir (Situs Uifana) adalah kampung ketiga, dan setelah Perang Dunia II, kampung tersebut ditinggalkan dan masyarakat menempati kampung baru yang sekarang.

Kampung lama Uifana, adalah kampung kedua setelah masyarakat mengenal agama (Islam). Di wilayah pemukiman, diantaranya terdapat struktur bangunan yang berciri kolonial, yang konon pada masa lampau difungsikan sebagai masjid. Selain itu terdapat struktur benteng tradisional (lutur) terdiri dari susunan batu yang cukup luas dan menampakkan adanya pembagian ruang. Data di lapangan pemukiman sudah memanfaatkan dinding-dinding susunan batu yang tertata rapi dan luas. Dinding batu adalah susunan batu karang, yang sebagian menunjukkan proses pemangkasan membentuk persegi. Dua buah sumur (parigi) yang dindingnya terbuat dari susunan batu, masih tersusun rapi, di bagian lain tampak struktur bangunan pintu gerbang, yang dekat dengan bibir sungai di bagian timur situs, tampaknya sebagai pintu masuk ke wilayah pemukiman.

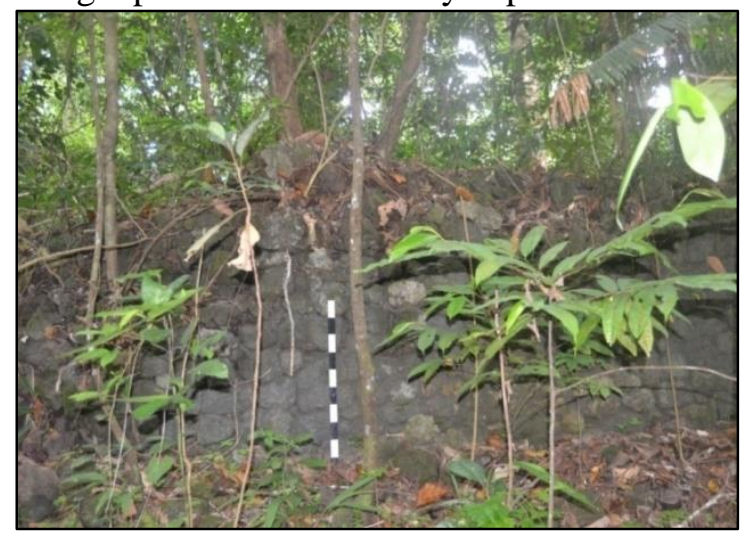

Gambar 6. Salah satu dinding struktur batu yang terletak di bagian tengah situ permukiman Lama Ujir yang disebut Uifana

(Sumber: Tim Penelitian, 2014)

Menurut deskripsi penelitian oleh Veth dan tim pada tahun 1996-1997 dan diterbitkan pada tahun 2005, struktur bangunan ini dianggap sebagai bagunan yang paling menonjol 
dibanding temuan lainnya. Ini adalah bangunan berbentuk persegi berukuran besar dengan pintu dan jendela melengkung, yang tersusun dari batu, dengan teknologi perekat atau plester kapur. Bagian atas jendela berbentuk melengkung, dan kondisi sekarang tampak tertimbun batu-batu karang. Di atas jendela yang berbentuk melengkung bagian atasnya, terdapat jejak bekas menempel piring keramik, bagian dari ornamen bangunan tersebut. Bangunan ini tampaknya didirikan paling belakangan, dibanding struktur lainnya di area situs pemukiman lama. Tampaknya digunakan sebagai masjid adalah penggunaan kembali (reuse) struktur yang sebelumnya sudah ada, dan mungkin lebih kompleks dari bangunan yang tampak sekarang (Veth, 2005). Selain bangunan itu, ciri bangunan lain yang terdapat pada lokasi yang sama menunjukkan konstruksi lokal. Oleh karena itu, menurut Veth, dkk (2005), keberadaan bangunan Eropa di tengah pemukiman berciri bangunan lokal menjadi tanda tanya. Veth (2005) menerangkan, selain satu-satunya bangunan berciri Eropa, indikasi lain pengaruh Eropa pada karakter permukiman lokal, hanya ditunjukkan adanya dua meriam dan jangkar asal Eropa, yang ditemukan di dekat pemukiman tersebut. Asal usul dan hubungan dengan struktur bangunan yang ada juga tidak jelas. Bangunan sejarah yang tercatat sebelumnya di Kepulauan Aru, adalah Benteng VOC Belanda, yang hanya terdapat di Wokam, Wangil dan Dosi yang dibangun pada adab $17 \mathrm{M}$ (Merton, 1910; Valentjin 1862; dalam Veth, et.al, 2005). Sebaliknya, bangunan yang terdapat di kampung kuno Ujir, sebelumnya tidak pernah tercatat.

Meski demikian, melihat konstruksi dan tata letak bangunan yang berada di tepi sungai, tampaknya bangunan itu awalnya adalah bangunan kolonial, yang pada masa kemudian difungsikan kembali untuk bangunan masjid, sangat mungkin setelah Kolonial tidak lagi berkuasa atas wilayah setempat. Pada masa Perang Dunia II dihancurkan kembali (Veth, 2005). Bangunan ini adalah bangunan yang paling menonjol, atau fitur utama yang terdapat pada situs pemukiman kuno Ujir. Bangunan berbentuk bangunan persegi dengan susunan batu dengan perekat atau plester kapur. Batu penyusun dinding adalah batuan koral. Tampak bangunan berlantai dua, dibagian bawah kemungkinan terdapat ruangan, namun kondisi sekarang tertutup oleh batu-batu yang sengaja diisi pada saat dialihfungsikan atau digunakan kembali (reuse) sebagai masjid. Bagian jendela yang berbentuk melengkung bagian atasnya, terisi oleh batu-batu koral atau karang. Di samping jendela yang melengkung, dibagian depan bangunan, tampak bekas tempat untuk melekatkan piring, yang kemungkinan piring keramik, sebagai ornament atau hiasan dinding bangunan..

Menurut informasi tutur, sebelum masjid ini hancur pada masa Perang Dunia II, bentuk masjid memiliki atap tumpang 3 susun dengan bagian puncak terdapat tiang alif, seperti pada umumnya bangunan masjid kuno lainnya di Maluku. Di Bagian depan masjid terdapat tangga naik, berjumlah dua. Tangga naik ini menurut penduduk digunakan untuk masuk melakukan shalat. Tangga kiri (sebelah timur) untuk kaum laki-laki, sedangkan tangga kanan (sebelah barat) untuk kaum perempuan. Kontruksi masjid berbentuk bujur sangkar, dengan ukuran 12, 50 $\mathrm{M}^{2}$. Di sebelah barat struktur masjid, terdapat sungai buatan yang kemungkinan pada masa lampau, sungai digunakan sebagai sungai pasang surut. (Veth, 2005). Penjelasan ini, kemungkinan digunakan untuk menampung debit air sungai yang meluap ketika air laut pasang, sehingga air tidak meluap masuk ke wilayah permukiman penduduk. Secara alami sungai menampung luapan air dari sungai. Masyarakat setempat menyebutnya sebagai fuabil. Hasil survei terbaru memperlihatkan bahwa pada bagian badan sungai sudah mengalami pendangkalan dan banyak ditumbuhi oleh berbagai pepohonan.

Selain itu bagian badan sungai dan area sekitarnya banyak ditemukan keramik dan tembikar yang cukup padat, bahkan ada pula sebaran kerang laut. Hasil survei Veth (2005), bahkan terdapat timbunan kerang setebal 10-15 $\mathrm{cm}$. Kanal ini ditutupi dengan timbunan sampah kerang sekitar 10-15 cm, yang terdiri dari spesies terutama bakau seperti Terebralia sp dan Anadara. Porselen Cina dan Eropa terdapat dalam timbunan sampah kerang. Tumpukan sampah kulit kerang, berada di bagian bawah keberadaan keramik. Dengan demikian, kerang tampak lebih dahulu ada sebelum keramik (Veth, 2005). Berdasarkan informasi tutur, disebutkan bahwa pada masa lampau di dalam badan sungai (fuabil) banyak dibuat lubang-lubang jebakan atau perangkap untuk menjebak musuh yang hendak menyerang kampong, oleh karena itu 
sebelumnya sering ditemukan tulang belulang di dalam sungai itu.

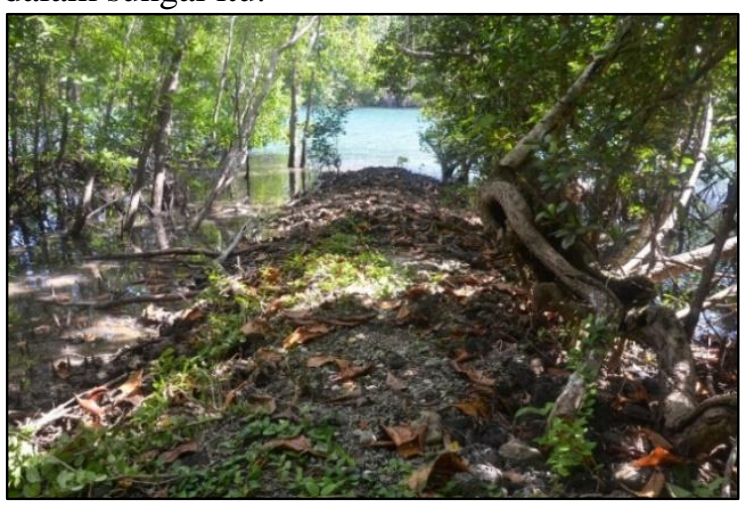

Gambar 7. Jalan dari situs pemukiman dengan dermaga dari arah pintu gerbang situs kampung lama Uifana

(Sumber: Tim Penelitian, 2015)

Di sebelah timur dari area situs pemukiman, terdapat fitur yang diduga sebagai sisa-sisa pintu gerbang dari dermaga sungai menuju pemukiman, berbentuk memanjang menghubungkan sungai dengan pemukiman. Dari pintu gerbang ke sungai dihubungkan jembatan atau jalan yang terbuat dari batu karang yang ditata, sehingga tampak sebagai jalan penghubung ataupun dermaga. Dengan demikian fitur ini menunjukkan bahwa pada masa lampau, situs ini intensif didatangi banyak orang dan bahkan sebagai wilayah jalur distribusi komoditi keluar dan masuk ke wilayah pemukiman.

Di dekat pemukiman terdapat beberapa bangunan dengan dinding struktur batu yang mengelingi sebuah makam yang dilengkapi dengan nisan. Makam ini juga dibangun dari batu karang yang dipangkas dan diplester. Masyarakat setempat menyebutnya kuburan panjang, dan kemungkinan merupakan makam dari tokoh penyebar Islam, atau tokoh yang memiliki status sosial yang tinggi, mengingat lokasi makam, menempati area khusus dan terpisah. Namun demikian, menurut Veth (2005) belum dapat dipastikan korelasi atau hubungan antara makam Islam terebut dengan pemukiman. Hasil wawancara dengan penduduk, disebutkan bahwa makam tersebut adalah makam penyebar Islam yang pertama kali di wilayah Pulau Ujir dan Kepulauan Aru. Berdasarkan orientasi makam yang mengarah utara selatan, makam yang dikelilingi oleh dinding karang diplester itu tampaknya menunjukkan dua makam, yang masing-masing terdiri satu nisan di bagian kepala. Selain makam, yang diduga makam Islam, tidak jauh dari lokasi itu juga terdapat makam, yang dikenal dengan makam Portugis.

\section{Situs Kampung Lama Uifana dalam Konteks Jaringan Niaga}

Peran Kepulauan Aru, hanya sedikit tercatat dalam historigografi lokal Kepulauan Maluku, baik menyangkut kesejarahan Islam maupun kolonial yang berkorelasi dengan perkembangan niaga. Dalam konteks jaringan Islamisasi, tampak ada hubungan kesejarahan wilayah Kepulauan Aru, dengan bagian perairan Maluku lainnya, seperti halnya Kepulauan Banda, bahkan terdapat pula tradisi tutur yang menyebutkan adanya pengaruh kekuasaan Islam Ternate dan Tidore, bahkan dari Sulawesi Selatan, yang direpresentasikan adanya komunitas mayarakat yang berasal dari Pulau Selayar (Jafar Hatala, pers.com, 2014).

Wilayah Kepulauan Aru, sebelumnya tidak cukup popular. Kepulauan Aru, melalui pulau Ujir, tampaknya memperlihatkan perannya sebagai wilayah lintasan jalur Islamisasi dan sekaligus perdagangan di wilayah selatan dan tenggara Kepulauan Maluku. Situs pemukiman lama dengan bukti-bukti perbentengan tradisional (lutur) dan artefakartefak seperti keramik membuktikan bahwa wilayah itu menjadi wilayah yang intensif memperoleh hubungan dengan pihak luar serta adanya hubungan yang sistematis membentuk pemukiman dan pusat-pusat transaksi antara masyarakat lokal dan para pedagang. Wilayah ini sangat memungkinkan menjadi jalur pertemuan atara wilayah Kepulauan Banda dan Kei di sebelah selatan dengan wilayah utara Kepulauan Maluku dengan wilayah Sulawesi.

Dari berbagai bukti, seperti pecahan keramik-keramik Cina, kemungkinan antara abad ke-17--18, wilayah Pulau Ujir menunjukkan perkembangan niaga, sekaligus Islamisasi. Usia perkampungan itu lebih tua karena keberadaan pemukiman tentu lebih dulu berkembang sebelum adanya aktifitas perdagangan. Pada pemukiman tersebut ditemukan adanya bekas-bekas perbentengan tradisional dengan rata-rata tinggi mencapai satu meter, dan sumur-sumur yang terbuat dari pahatan batuan koral. Kampung itu, seperti yang sudah disebutkan sebelumnya, juga dikelilingi oleh sungai buatan yang menjadi konsep pertahanan masyarakat, meskipun kemudian 
porak-poranda ketika perang melawan Jepang, dan masyarakatnya pindah ke Desa Ujir yang sekarang.

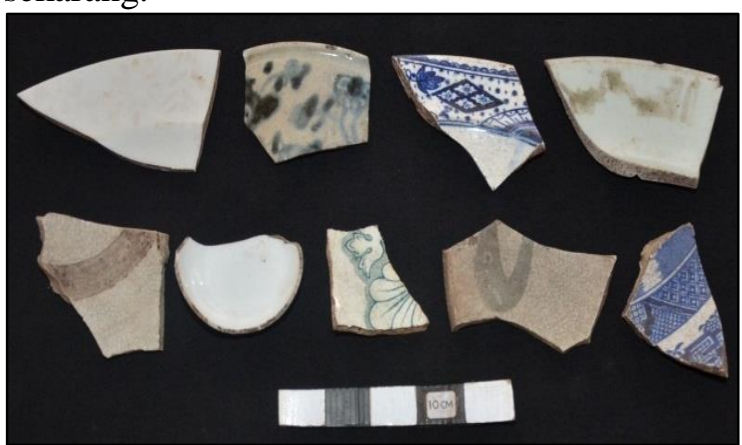

Gambar 8. Berbagai jenis keramik yang ditemukan dari hasil ekskavasi

(Sumber: Tim Penelitian, 2015)

Dalam konteks kronologi permukiman dan Islamisasi di Pulau Ujir, tampaknya berhubungan dengan peran Kepulauan Aru dalam jaringan perdagangan burung cendrawasih dan rempah-rempah, sejak 2000 tahun yang lalu. Peran Kepulauan Aru, tidak dapat dipisahkan dengan wilyah Pulau Banda, sebagai entreports dari perdagangan komoditas berharga (Meilink-Roelofsz, 1962).

Sebelum dan selama periode kehadiran Portugis di wilayah Kepulauan Aru, tidak bisa dilepaskan jaringannya dengan wilayah Pulau Banda, karena sebagian besar perdagangan pada masa itu dikuasai oleh jalur lintasan perdagangan dari Pulau Banda. Oleh karena itu Kepulauan Aru dan kelompok pulau-pulau terdekat, selalu berhubungan dengan Banda dalam hal pertukaran burung cendrawasih dan burung beo dengan kain yang didatangkan dari Banda. Selain itu temuan tembikar slip merah, baik di wilayah Banda, ataupun di Kepulauan Aru, tepatnya di situs Wangil, menunjukkan adanya jaringan perdagangan kuno pra kolonial yang menukarkan tembikar dan kain dari Banda ke Aru. Beberapa emas juga dikatakan telah datang dari Aru asal usulnya pasti dari Nugini Barat, mungkin melalui jalur perdagangan lain melalui Gorom dan pulau-pulau Seram Laut di sebelah timur Pulau Seram menuju Aru (Goodman, 1998; Villiers, 1981: 74).

Courtesao menunjukkan, bagian ini tidak menggambarkan perjalanan Abreo, namun pelayaran perdagangan Jawa. Sejak awal abad ke- 14 Kerajaan Majapahit di Pulau Jawa memiliki pengaruh di wilayah Maluku akibat rempah-rempah, antara Ambon dan Maluku
(Maluku Utara). Kontak dengan Jawa mendorong berkembangnya para sultan seperti Ternate di Maluku Utara (Reid, 1953: 315; Swalding, 1996: 23). Dorongan utama dari perjanjian 1623 adalah upaya untuk menghidupkan kembali perdagangan kuno antara Banda dan Aru berhenti selama perang pemusnahan di Banda pada kuartal pertama abad 16-17, perpanjangan perdagangan ini di bawah monopoli VOC memungkinkan Belanda untuk mengurangi tingginya biaya transportasi bahan makanan dari Jawa ke Banda melalui impor sagu dan tanaman lain yang dihasilkan Kepulauan Aru.

Kesepakatan berikutnya 1645 untuk desadesa yang sama untuk perdagangan secara eksklusif dengan Belanda dikontrol Banda. Mungkin struktur benteng di Pulau Ujir dibangun dengan inspirasi dari bangunan Belanda. Tahun 1826 kunjungan Koffs ke Ujir, yang disebut Wadia, menyediakan referensi langsung tentang reruntuhan yang berada di tepi sungai. Namun menurut Koffs bahwa struktur yang kemudian digunakan sebagai masjid, mungkin bukan pengaruh dari Belanda. Dia melaporkan sengketa antara Ujir dan sebuah desa bernama 'Fannabel' di sisi timur laut dari Wokam. Orang Tua dari Fannabel, dikatakan memiliki bangunan batu, didukung adanya meriam, yang mungkin dari periode yang sama dengan berdirinya struktur benteng di Ujir. Petunjuk lebih lanjut ke zaman kuno dan cukup penting dari situs Ujir, berasal dari risalah di Kepulauan Aru oleh van Hoevell dan Merton (1910) dari Zoologi Jerman. Selama perjalanan ke Pulau Aru pada tahun 1888 Baron van Hovell mencatat bahwa masjid batu Ujir bisa dilihat dari salah satu muara (sungai).

Yang menarik dari observasi ini adalah, Ujir memiliki benteng paling besar dari salah satu masyarakat indegenous dan tampaknya ada dinding yang luas, berasal dari periode waktu sebelumnya. Selain itu, susunan batu benteng tradisional (lutur) yang lebih tua dari bangunan berciri Eropa, menunjukkan bahwa pemukiman mungkin sudah ada sebelumnya atau bersamaan hadirnya dengan pedagang Islam. Hasil survei permukaan pada situs pemukiman kuno Uifana atau kampung kuno Ujir, menunjukkan prosentasi periode perkembangan keramik yang dapat digunakan untuk menduga kronologi situs Ujir. Dalam analisis ini perkiraan kronologi berasal dari analisis kualitatif dan kuantitatif 
keramik yang berasal dari permukaan. Dari analisis keramik peneltian ini diketahui sebagian besar keramik yang diidentifikasi berasal dari Cina dari Dinasti Ming hingga Qing abad ke- 16$20 \mathrm{M}$; keramik dari Jepang Hizen ware abad ke18 dan 19, juga keramik dari Eropa (abad ke- 1920). Berdasarkan periode keramik, maka perkembangan niaga dapat diketahui berkembang sejak abad ke- 16 dan terus berkembang hingga mencapai puncaknya pada abad ke- 18-19 dan kemudian abad ke- 20 memasuki periode pascakolonial, atau pada masa setelah pendudukan Jepang.

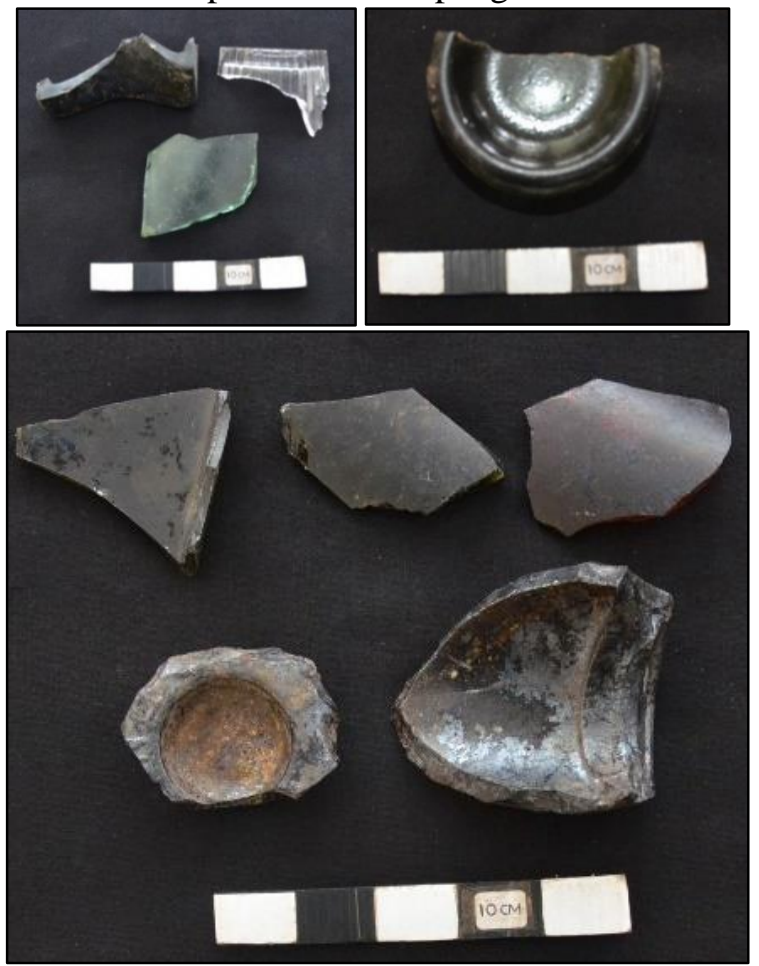

Gambar 9. Beberapa fragmen kaca yang diperoleh dari hasil ekskavasi

(Sumber: Tim Penelitian, 2015)

Persebaran keramik membuktikan secara jelas, jaringan yang terjadi pada masa lampau antarwilayah di dalam negeri, bahkan hubungan jarak jauh antar negara dan benua (Harkantiningsih, 2006: 17-23). Pemukiman kuno Ujir memberikan bukti bahwa, wilayah itu memiliki peran cukup penting dalam sejarah perkembangan niaga, sementara kedudukannya sebagai wilayah yang pertama kali penduduknya menerima Islam merupakan isu penting yang perlu pendalaman kajian. Tampaknya, pemukiman kuno dengan susunan batu yang membentuk pembagian ruang, merupakan bukti bahwa kehidupan sosial budaya masyarakat telah berkembang. Pengaruh struktur bangunan Islam di Pulau Ujir mungkin berhubungan dengan wilayah Ujir sebagai penghasil sagu dan suplai burung cendrawasih. Pada tahun 1623 Gubernur Ambon mengirim dua kapal di bawah Jan Cartensz untuk menandatangani perjanjian persahabatan dengan orang kaya atau pedagangbangsawan desa di pantai barat Aru (Veth, 2005).

Pada awal abad ke-19, wilayah Kepualuan Aru telah dibagi menjadi empat kabupaten di bawah kekuasaan Ujir, Wokam, Wamar dan Maikoor. Sejak saat itu, desa-desa tersebut memainkan peran penting bertindak sebagai mediator dalam perselisihan lokal di Kepulauan Aru (Spyer, 1992: 58, 60, 63 dalam Veth, 2005: 90). Dari segi geografis, kedudukan Pulau Ujir sebagai situs pemukiman kiranya sangat penting karena berada pada pintu masuk ke wilayah Kepulauan Aru. Diperkirakan kapal-kapal pedagang datang dari wilayah Kei dan Banda ataupun wilayah Maluku lainnya melalui perairan di depan Pulau Ujir. Berbagai temuan artefaktual komoditi perdagangan yang terdapat di Pulau Ujir dengan kuantitas yang melimpah menunjukkan Ujir adalah salah satu pulau tujuan. Dengan demikian, diperkirakan sudah ada hunian yang berkembang pada awal kedatangan bangsa asing.

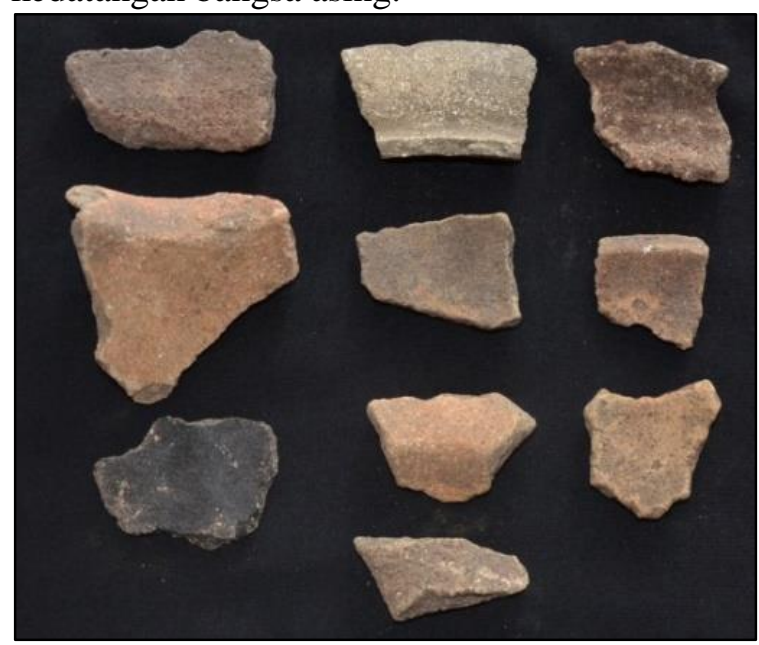

Gambar 10. Temuan Tembikar Hasil Ekskavasi Situs Uifana, Pulau Ujir, Kepulauan Aru (Sumber: Tim Penelitian, 2015)

Dalam beberapa sumber sejarah, khususnya terkait dengan perkembangan niaga di wilayah Kepulauan Maluku, tampaknya masih terbatas hasil penelitian dan pengetahuan tentang Kepualuan Aru. Meski demikian, 
Mahartono (1993) telah merekam pertukaran antara pantai dan daerah pedalaman Nusa Tenggara Timur, Pulau Aru, Maluku Tenggara yakni barang tembikar ditukar dengan produk panenan lokal, untuk dijual kembali di pasar (Nayati 2004). Dalam banyak kesempatan pembagian kembali produk hanya memerlukan, dua atau tiga para pedagang untuk menjangkau pembeli. Pembagian barang-barang kadangkadang memerlukan banyak usaha dan waktu. Pedagang tembikar di Pulau Aru, menukar komoditinya itu untuk memperoleh tananam penenan, kemudian menjualnya kembali di pusat niaga di Dobo.

Studi Taurn (1918) menyangkut pendistribusian komoditi dari wilayah Gesser, Seram Bagian Timur ke pulau-pulau lainnya sangat berharga untuk dikembangkan dalam berbagai penelitian baik arkeologi maupun sejarah untuk melihat mekanisme perdagangan diantara pelabuhan-pelabuhan niaga di Kepulauan Maluku. Dalam kasus ini, ramainya proses perdagangan pada masa lampau, terjadi tukar menukar komoditi andalan dari setiap daerah niaga ke daerah niaga lainnya. Hal ini karena persaingan dagang antara daerah-daerah niaga. Setiap daerah niaga, berupaya mengembangkan produk atau komoditinya yang mungkin tidak dimiliki oleh daerah lainnya. Contoh kasus pada masa kini daerah Kepulauan Aru dan Kepualuan Nusa Tenggara merupakan daerah yang terkenal dengan budidaya mutiara, yang ditukarkan atau diperdagangkan ke wilayah lainnya di kepulauan Maluku. Pada kasus yang sama hal ini mungkin juga telah berlangsung sejak masa lampau. Dalam sebuah studinya di wilayah Maluku Tenggara Nayati juga menjelaskan, perdagangan lokal tidak saja dilakukan oleh pedagang lokal, namun juga terdapat pedagang asing, meskipun penyaluran kembali produk atau komoditi ke daerah pedalaman dilakukan oleh pedagang lokal. Di wilayah Watulai (Aru Island), para pembuat tembikar, menukarkan produknya dengan sebagai barang perdangangan di pasar (Nayati, 1998; Nayati, 2005).

Melihat fenomena ini, tampaknya peran pulau Ujir yang diwakili situs pemukiman kuno Ujir atau situs Uifana, tampaknya memberikan gambaran tentang wilayah-wilayah pemukiman di Kepulauan Aru sebagai lokasi transaksi perdagangan. Pulau Ujir yang diwakili oleh situs Uifana adalah situs pemukiman kuno Islam yang mungkin memiliki peran sebagai pemukiman pertama yang mendapat pengaruh Islam dan kemudian menyebar ke wilayah lain di Kepulauan Aru. Bukti-bukti tentang perkembangan Islam, adalah jejak pemukiman, benteng-benteng tradisional, bangunan kolonial yang digunakan sebagai masjid yang mungkin difungsikan paska kolonial, serta bukti-bukti artefaktual yang diperdagangkan pada periode Islamisasi sejak abad ke-16 dan 17, hingga pada masa pendudukan dan perkembangan niaga pada masa Kolonial. Pada masa Kolonial, menurut tradisi tutur setempat dalam rentang waktu tertentu, kontrolir Belanda yang berkedudukan di Pulau Wokam, senantiasa datang dengan menggunakan kapal kecil ke Ujir untuk mengontrol distribusi barang dari Ujir untuk dipasarkan di Wokam maupun di Dobo. Oleh karena itu kedudukan Ujir, merupakan salah satu pulau yang diperhitungkan perannya dalam lintasan jalur niaga di Kepulauan Aru dan ke wilayah lainnya seperti Kepulauan Banda, Kei, Seram bahkan pesisir Papua.

\section{KESIMPULAN}

Hasil penelitian secara keseluruhan terhadap data arkeologi yang terdapat di wilayah Ujir, memberikan gambaran tentang perkembangan pemukiman masyarakat Ujir sekaligus perkembangan niaga yang memainkan peran wilayah itu. Interpretasi tentang perkembangan Islam, dapat diajukan bahwa situs pemukiman kuno Ujir merupakan pemukiman kuno Islam. Hal ini ditandai oleh bangunan yang digunakan sebagai masjid serta struktur-struktur batu penyusun benteng tradisional yang mungkin digunakan sebagai benteng-benteng pertahanan tradisional ataupun sebagai dinding-dinding ruang berdasarkan kelompok marga yang bermukim di situs tersebut.

Data artefaktual keramik, pada periode abad ke-16-17, 18-19, serta 19-20, memberikan gambaran tentang kronologi hunian di situs-situs Pulau Ujir, sekaligus perkembangan pemukiman, sekaligus perkembangan Islam di dalamnya dan perniagaan. Kuantitas data artefaktual serta masifnya data-monumental, menggambarkan bahwa situs pemukiman kuno Pulau Ujir, merupakan pemukiman yang cukup padat dan ramai, bahkan adanya pintu gerbang yang menghubungkan pemukiman dengan sungai, menunjukkan bahwa situs tersebut 
tempat yang sering didatangi oleh orang luar, serta mobilisasi penduduk ke dan dari luar wilayah yang cukup ramai. Tampaknya, situs kuno Uifana di Pulau Ujir, memainkan peran penting sebagai pintu masuk perdangangan dan pada masa perkembangan awal berperan sebagai pusat penyebaran Islam dan pintu masuk berkembangnya Islam ke wilayah lain di Pulau Aru. Perkembangan niaga pada periode berikutnya, yakni pada masa kolonial, menciptakan dinamika yang kompleks, dimana perdagangan di satu sisi semakin ramai, namun hegemoni kolonial atas wilayah itu juga sangat tajam. Berdirinya bangunan di tepi sungai berciri kolonial, serta bangunan makam-makam Eropa di wilayah sekitar pemukiman kuno, menjelaskan bahwa kedudukan Pulau Ujir sangat penting di mata kolonial. Kedudukan pusat kekuasaan Belanda di Kota Lama, Wokam dengan mendirikan benteng disana, mungkin salah satunya untuk mengontrol aktivitas masyarakat di Pulau Ujir. Hal itu karena mungkin Pulau Ujir tidak bisa dikuasai sepenuhnya oleh Belanda.

Tampaknya situs Ujir merupakan medan penelitian yang cukup potensial untuk dikembangkan dan diperdalam, untuk mengkaji berbagai kemungkinan yang muncul dari data penelitian yang ditemukan. Pada konteks ini, Pulau Ujir, merupakan situs pemukiman kuno, sebagai pusat penyebaran Islam sekaligus pintu masuk penyebaran Islam di wilayah sekitarnya. Selain itu kedudukannya cukup penting menghubungkan jaringan perdagangan dari dan keluar wilayah Kepulauan Aru, baik dalam jalur lintasan dari Pulau Banda, maupun dengan wilayah timur Pulau Seram, seperti Pulau Gorom dan bahkan lintasan dengan wilayah Papua.

Rekomendasi penting dalam hal ini adalah penelitian dan penanganan temuan arkeologis yang sistematis serta program-program revitalisasi dan pelestarian situs yang melibatkan kerjasama antar instansi yang terkait, stakeholder dan masyarakat setempat. Selain itu perlunya sosialisasi di masyarakat setempat tentang peran penting situs-situs arkeologi di wilayah Pulau Ujir, agar semakin kuat kesadaran masyarakat untuk melestarikan sebagai bagian upaya mempertahan nilai-nilai sejarah dan budaya sekaligus memahami jatidiri melalui peninggalan masa lampau.

\section{Ucapan Terima Kasih}

Penulis mengucapkan terima kasih kepada saudara Muhammad Al Mujabuddawat atas bantuannya dalam penyiapan peta dan gambar. Terima kasih juga untuk saudara Cheviano Alputila yang membantu analisis keramik hasil penelitian ini.

$$
* * * * *
$$

\section{DAFTAR PUSTAKA}

Ambary, Hasan Muarif. (1998). Menemukan Peradaban Arkeologi dan Islam di Indonesia. Jakarta: Pusat Penelitian Arkeologi Nasional. Logos. Wacana Ilmu. Jakarta.

Harkantiningsih, Naniek. (2006). Aspek Arkeologi dalam Penelitian Keramik. Orasi Ilmiah Dalam Pengukuhan Profesor Riset Bidang Arkeologi. Jakarta Pusat Penelitian dan Pengembangan Arkeologi.

Leirizza. (2001). Jalur Sutera: Integrasi Laut-Darat dan Ternate sebagai Bandar di Jalur Sutera. Dalam M.J. Abdulrahman, et.al. Ternate: Bandar Jalur Sutera, Ternate: LinTas (Lembaga Informasi dan Transformasi Sosial).

Lape, P.V. (2000a). Contact and Conflict in the Banda Islands, Eastern Indonesia, 11th to 17th Centuries. Unpublished $\mathrm{PhD}$ thesis, Brown University, Rhode Island.

Lape, P.V. (2000b). Political dynamics and religious change in the late pre-colonial Banda Islands, Eastern Indonesia. World Archaeology 32(1).

Nayati, Widya. (2005). Social Dynamics and Local Trading Pattern in the Bantaeng Region, South Sulawesi (Indonesia) circa 17th century. A Thesis Submitted For The Degree Of Doctor Of Philosophy The Southeast Asian Studies Programme. National University Of Singapore.

O'Connors, Sue, Veth, PM., Spriggs, M. (2007). The Archaeology of the Aru Islands, Eastern Indonesia. Canberra. Australian National University Press.

Veth, Peter, Sue O'Connor, Matthew Spriggs, Widya Nayati, Ako Jatmiko, and Husni Mohammad. (2006). The Ujir Site: An Early Historic Maritime Settlement in Northwestern Aru. The Archaeology of the Aru Islands, Eastern Indonesia. Canberra. Australian National University Press.

Putuhena, Shaleh. (2001). Proses perluasan agama Islam di Maluku Utara. Dalam M.J. Abdulrahman, et.al. Ternate: Bandar Jalur Sutera, Ternate: LinTas (Lembaga Informasi dan Transformasi Sosial). 
Sharer, dan Ashmore. (1980). Fundamentals of Archaeology. London: The Benjamin Cummings Publishing Company.

Spriggs, Matthew. (1998). Research Questions in Maluku Archaeology. Cakalele, vol. 9, No. 2 (1998): Australian National University. 51-64.

Ricklefs, M.C. (2008). Sejarah Indonesia Modern 1200-2004. Jakarta. PT Serambi Ilmu Semesta.

Taurn, Odo Deodatus. (1918). Patasiwa und Patalima vom Molulukeneiland Seran und Seinen Beoners. Leipzig. Terjemahan Dra.Ny.Hermelin T tahun 2001. Balai Kajian Sejarah dan Nilai Tradisional Maluku dan Maluku Utara 2001.

Tjandrasasmitha, Uka. (2009). Arkeologi Islam Nusantara. Jakarta. Kepustakaan Populer Gramedia (KPG).

Wallace, Alfred Russel. (2009). Kepulauan Nusantara: Sebuah Kisah Perjalanan Kajian Manusia dan Alam. Jakarta: Komunitas Bambu.

Wakim, Mezak. (2014). Kepulauan Aru dan Integrasi Kebangsaan dalam Perspektif Sejarah Budaya. Kapata Arkeologi. Vol. 10 No. 1. Juli. Ambon. Balai Arkeologi Ambon. 